\title{
Phenoxylation of Alkynes Through Mono- and Dual-Activation using Group 11 (Cu, Ag, Au) Catalysts
}

\author{
Miguel Ramos, ${ }^{[a]}$ Jordi Poater, ${ }^{*[b, c]}$ Nery Villegas-Escobar, ${ }^{[d]}$ Martí Gimferrer, ${ }^{[a]}$ Alejandro Toro-Labbé, ${ }^{[d]}$ \\ Luigi Cavallo*[e] and Albert Poater*[a]
}

Dedicated to Prof. Dr. Walter Thiel

\begin{abstract}
NHC-gold(I) based catalysts have displayed outstanding results toward hydroalkoxylation of terminal and internal alkynes in solvent-free conditions and using low catalyst loadings. It has been demonstrated that in the hydrophenoxylation reaction the gold complex is composed by two moieties that determine the rate of the reaction by activating both substrates synergistically, i.e. $[\mathrm{Au}(\mathrm{OR})(\mathrm{NHC})]$ and $\left[\mathrm{Au}\left(\mathrm{n}^{2} \text {-alkyne }\right)(\mathrm{NHC})\right]^{+}$. Then, these bimetallic systems act cooperatively toward hydroalkoxylation reaction. Herein, density functional theory studies were carried out to get insights on the mechanism of hydrophenoxylation. The rate-determining step which corresponds to the formation of the $\mathrm{C}$ (alkyne)-O(alcohol) bond between $[\mathrm{Au}(\mathrm{OR})(\mathrm{NHC})]$ and $\left[\mathrm{Au}\left(\eta^{2} \text {-alkyne }\right)(\mathrm{NHC})\right]^{+}$, was studied using energy decomposition analyses (EDA). It was found that the $\mathrm{C}$ $\mathrm{O}$ bond shows strong electrostatic and orbital interactions between both fragments in the homobimetallic, heterobimetallic and monogold mechanisms. Moreover, the analyses were expanded to copper and argentum, and the steric sensibility was also studied through the use of different NHC ligands, including IMes, IMe, SIMes, IPr, and IPr*, that differ on their steric demand.
\end{abstract}

\section{Introduction}

Chemical reactions are typically harmful to the environment because of waste generation, which has become a society issue. Controlling and improving organic transformations has always been a strong desire of the chemistry community. But the design

[a] M. Ramos, M. Gimferrer, Dr. A. Poater

Institut de Química Computacional i Catàlis

Departament de Química, Universitat de Girona

c/ Maria Aurèlia Capmany 69, 17003 Girona, Catalonia (Spain)

E-mail: albert.poater@udg.edu

Homepage: https://albertpoater.wordpress.com

[b] Dr. J. Poater

Departament de Química Inorgànica i Orgànica \& IQTCUB

Universitat de Barcelona

Martí i Franquès 1-11, 08028 Barcelona (Spain)

E-mail: jordi.poater@ub.edu

[c] Dr. J. Poater

ICREA

Pg. Lluís Companys 23, 08010 Barcelona (Spain)

[d] N. Villegas-Escobar, Prof. Dr. A. Toro-Labbé

Laboratorio de Química Teórica Computacional (QTC), Facultad de Química y de Farmacia, Centro de Energía UC

Pontificia Universidad Católica de Chile

Avenida Vicuña Mackenna 4860, Santiago 7820436, Chile

[e] Prof. Dr. L. Cavallo

King Abdullah University of Science \& Technology

KAUST Catalysis Center (KCC)

23955-6900 Thuwal, Saudi Arabia

E-mail: luigi.cavallo@kaust.edu.sa

Supporting information for this article is given via a link at the end of the document. of more atomistically economic and sustainable reactions, by reducing the waste, is a great challenge. For instance, poly(vinyl ethers) are compounds with a great value in coating industry, which is devoted to the synthesis of its monomer precursors, i.e. vinyl ethers (VEs). VEs are often synthesized using transition metals catalysts to carry out the addition of alcohol to an alkyne. ${ }^{[1,2]}$ Actually, the process of addition of alcohol to alkynes moved from the use of toxic mercury(II) salts to the pioneering catalytic work of Teles and coworkers by employing cationic phosphane-gold(I). ${ }^{[3]}$ Afterwards, Houk, Toste and coworkers shed light into gold catalysis, providing evidence that two gold centres may form a diaurated complex that synergistically cooperate to accomplish the cycloisomerization reaction. ${ }^{[4]}$ The mechanism proceeded through the activation of an in situ formed phosphinegold(I) acetylide by cationic phosphinegold(I). One year later, the Gasgosz's group studied a similar reactivity for the phosphinegold(I) catalyst highlighting its unusual dual character as nucleophile (C-H activation) and electrophile (alkyne activation).[5] These pioneering discoveries in cyclization reactions with allenyne and dyines, which contain a $\mathrm{C}-\mathrm{C}$ triple bond, enabled gold to form the so-called $\sigma, \pi$-digold-acetylide complex. ${ }^{[6,7]}$ This latter complex represented a landmark together with the introduction of $\mathrm{N}$-heterocyclic carbene $(\mathrm{NHC})$ ligands by means of the stable gem-diaurated $\left[\{\mathrm{Au}(\mathrm{NHC})\}_{2}(\mu-\mathrm{OH})\right]$ species discovered by Nolan and coworkers in 2013..$^{[8,9,10,11]}$ The dual gold catalysis then expanded the number of catalytic applications. ${ }^{[12,13,14,15,16,17,18,19]}$

Apart from the experimental characterization by Roithóva and coworkers, ${ }^{[20,21]}$ Poater et al. made further efforts by deepening in the mechanism for the hydrophenoxylation of alkynes, ${ }^{[22,23]}$ confirming the readily capacity of gem-digold hydroxides to dissociate and re-associate; the poor reactivity of phenol in monoaurated systems; $[24,25,26]$ and the active role of water. Actually, in the framework of dual activation applied in the hydroalkoxylation or hydrophenoxylation of alkynes, the reaction proceeds mildly under low catalyst loadings. Using density functional theory (DFT) calculations, assistance from substrates was checked to be of high relevance in the process. ${ }^{[27]}$ In the C$O$ bond formation step, the dual gold catalysed phenoxylation of diphenylacetylene mechanism left out of the game that of the mono catalysed one, $\left.{ }^{[28}\right]$ having two alcohol molecules to cooperatively conduct the nucleophilic attack, by displaying a lower energy barrier (see Figure 1). However, the nature of the alcohol substrate, and the potential role of the counteranion of the catalyst displace the delicate equilibrium between the mono and dual catalysis. ${ }^{[29,30,31,32,33,34]}$ 
(a)

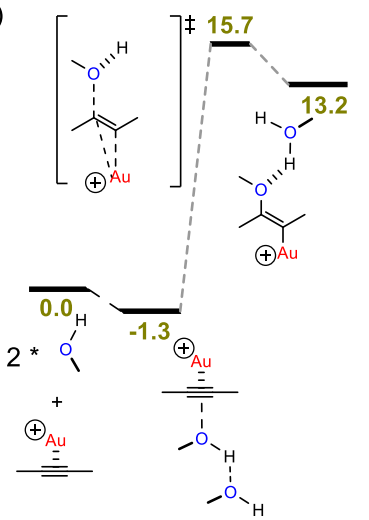

(b)

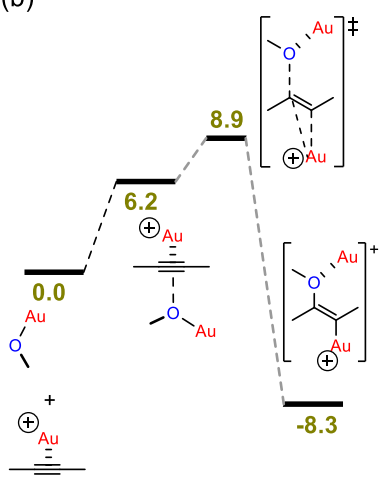

Figure 1. Reaction profile of the phenoxylation of dimethylacetylene by (a) mono- and (b) dual-gold catalysis. Gibbs free energies were computed at the M06/TZVP $\operatorname{sdd}(\mathrm{Au}) / / \mathrm{BP} 86 / \mathrm{SVP} \sim \mathrm{sdd}(\mathrm{Au})$ level of theory and reported in kcal $\mathrm{mol}^{-1}$. Note that $[\mathrm{Au}]=\mathrm{Au}(\mathrm{IMe}) .^{[23]}$

Heterobimetallic complexes have been also matter of study due to the fact that the bifunctionality of different metals can lead to unique reactivity. Recent work by Cazin et al. reported the hydrophenoxylation of internal alkynes with heterobimetallic $\mathrm{Cu}$ $\mathrm{NHC} / \mathrm{Au}-\mathrm{NHC}$ systems. ${ }^{[35]}$ in line with previous works on two metal moieties bearing different metal nature. ${ }^{[36,37,38]}$ Later on, Poater and coworkers described computationally the hetero-dual catalysis for group $11,{ }^{[39]}$ and the most efficient system predicted for hydrophenoxylation reaction was $\pi-A u / \sigma-A g$. It is worth noting that the earth abundant copper(I) system can also perform efficient activation of phenol to carry out the nucleophilic attack. Furthermore, various NHC ligands were tested to see the relevance of the steric and electronic properties that these moieties play in the process of $\mathrm{C}-\mathrm{O}$ bond formation. From the latter analysis, it was found that medium size NHCs present more favourable formation energies.

The main goal of the present research is to give a detailed characterization of the $\mathrm{C}-\mathrm{O}$ bond formation that takes place in the hydrophenoxylation of alkynes. The latter step is known to be the limiting step, in which efforts to make this process more costeffective have been done through chelation of the complex or by exchanging the metal center. Chemical bonding analyses between the two aurated building blocks that perform the hydrophenoxylation of alkynes reaction were carried out. The dual metallic and the homologous monogold catalysed toward the C$O$ bond formation were taken into account for the sake of comparison. ${ }^{[40,41,42,43]}$ Furthermore, the nature of the metal together with the role of the $\mathrm{NHC}$ ligand are considered, by tuning its steric and electronic contributions to the metal centre.

\section{Results}

To better understand the effect of cooperative catalysis, the binding energy (BE) of the two moieties (alkynes and alcohols) that lead to the $\mathrm{C}-\mathrm{O}$ bond formation were investigated. Herein, we get insight into the $\mathrm{C}-\mathrm{O}$ bond formation step of hydrophenoxylation of alkynes catalysed by digold systems,

together with some monoaurated ones for the sake of comparison. Likewise, systems bearing two gold centres, each one activating either an alcohol or an alkyne to form $[\mathrm{Au}(\mathrm{OR})(\mathrm{NHC})]$ and $\left[\mathrm{Au}\left(\mathrm{n}^{2}-\right.\right.$ alkyne)(NHC) $]^{+}$fragments, respectively, are taken into study. This process has been studied along with the dicuprated and diargentic analogs, together with the combined bimetallic systems. Furthermore, a set of NHC ligands will be used to evaluate the role of their steric hindrance in the $\mathrm{C}-\mathrm{O}$ bond formation process. Particularly, five different NHC ligands are used for calculations: $\mathrm{IMe}=1,3$-dimethylimidazol-2-ylidene, $\mathrm{IPr}=\mathrm{N}, \mathrm{N}^{\prime} \quad$-bis $(2,6-$ bis(dimethylmethyl)-4-methylphenyl)imidazol-2-ylidene, SIMes = $\mathrm{N}, \mathrm{N}^{\prime} \quad$-bis(2,4,6-trimethylphenyl)-4,5-dihydroimidazol-2-ylidene, IMes = N,N' -bis(2,4,6-trimethylphenyl)imidazol-2-ylidene and the highly sterically hindered $\mathrm{IPr}^{*}=\mathrm{N}, \mathrm{N}^{\prime}$-bis $(2,6$ bis(diphenylmethyl)-4-methylphenyl)imidazol-2-ylidene (see Scheme 1). ${ }^{[44,45]}$

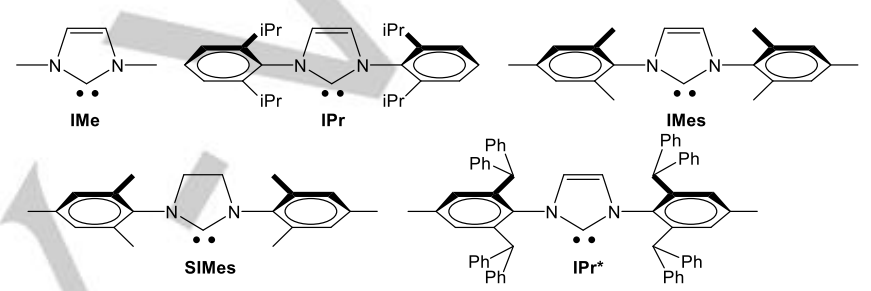

Scheme 1. N-heterocyclic carbenes used in this study.

The nature of the C-O bond formation by both dual cooperative or monogold catalysis is studied. In particular, for the monogold path, only the alkyne moiety is activated by the aurated catalyst due to the high $\pi$-acidity character and low oxophilicity of the cationic gold(I) species. After the activation through the gold catalyst, inactivated nucleophiles, e.g. alcohols (in particular of alkylic-type), would conduct a nucleophilic attack onto the alkynes, leading to the $\mathrm{C}-\mathrm{O}$ bond formation.

In Table 1, binding energies (BE) of different alkynes and alcohols are displayed to reveal how the nucleophilic attack of monogold systems proceeds in contrast to digold ones. Here, $[\mathrm{Au}(\mathrm{R}-\mathrm{CC}-\mathrm{R})(\mathrm{IMe})]^{+}$species possess an internal alkyne such as diphenylacetylene (Ph-CC-Ph), dimethylacetylene $\left(\mathrm{CH}_{3}-\mathrm{CC}-\mathrm{CH}_{3}\right)$ or di(trifluoromethyl)acetylene $\left(\mathrm{CF}_{3}-\mathrm{CC}_{-}-\mathrm{CF}_{3}\right)$. This cationic fragment then reacts with either methanol $(\mathrm{MeOH})$ or phenol $(\mathrm{PhOH})$. Instead, in the dual metal catalytic mechanism, the latter free alcohol molecules are replaced by $\mathrm{NHC}$-gold(I) alkoxide complexes $[\mathrm{Au}(\mathrm{OR})(\mathrm{IMe})](\mathrm{R}=\mathrm{Ph}, \mathrm{Me}) \cdot{ }^{[46]}$ Additionally, the IMe $\mathrm{NHC}$ will introduce a moderately low steric hindrance on the metal sphere, which is used as model to compare larger NHCs latter in the study.

The energy landscape for the $\mathrm{C}-\mathrm{O}$ bond formation consists of three points: (a) a reactive complex formed as the two building blocks are located rather far; (b) the transition state (TS), which involves the nucleophilic attack, and $\mathrm{C}-\mathrm{O}$ bond formation starts taking place; and (c) the VE intermediate with total formation of the $\mathrm{C}-\mathrm{O}$ bond. In the simplest case, a methanol molecule carries out the nucleophilic attack on the activated alkyne (Figure 2). 


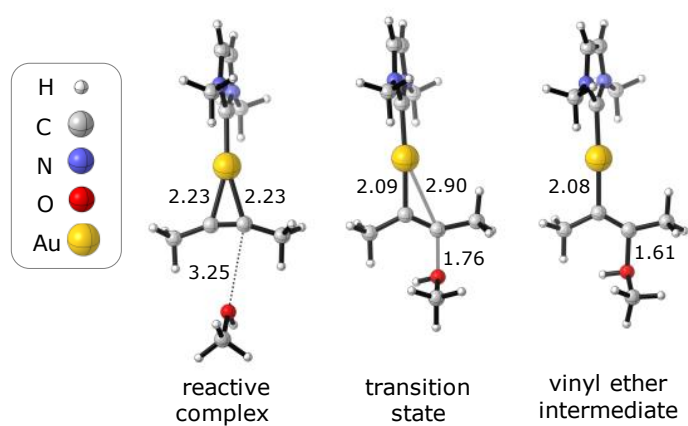

Figure 2. Main structures for the monogold $\mathrm{C}-\mathrm{O}$ bond formation mechanism. Selected distances are shown in $\AA$.
Results for methanolic hydroalkoxylation (Table 1) clearly suggest a preference for the dual catalysis since the kinetics are favored by $5 \mathrm{kcal} \mathrm{mol}^{-1}$ compared to the most favored system bearing a fluoride substituted alkyne on gold and two free methanol moieties. In the monogold system, one and two alcohol molecules were taken into account. When two alcohol molecules are considered, the second alcohol molecule stabilizes the alcoholic proton, increasing the nucleophilic capacity of the hydroxy group.

Table 1. Binding, interaction and deformation Gibbs energies for the nucleophilic C-O bond formation. Energies are given in kcal mol 1. $(\mathrm{RC}=$ reactant complex; TS $=$ transition state; VE interm = vinyl ether intermediate; $[\mathrm{Au}]=\mathrm{Au}(\mathrm{IMe}))$

\begin{tabular}{|c|c|c|c|c|c|c|c|c|c|c|c|}
\hline Frag1 & & $\begin{array}{c}{[\mathrm{Au}]^{+}} \\
(\mathrm{MeCCMe})\end{array}$ & $\begin{array}{c}{[\mathrm{Au}]^{+}} \\
(\mathrm{MeCCMe})\end{array}$ & $\begin{array}{c}{[\mathrm{Au}]^{+}} \\
(\mathrm{MeCCMe})\end{array}$ & $\begin{array}{c}{[\mathrm{Auu}]^{+}} \\
(\mathrm{PhCCPh})\end{array}$ & $\begin{array}{c}{[\mathrm{Au}]^{+}} \\
(\mathrm{PhCCPh})\end{array}$ & $\begin{array}{c}{[\mathrm{Au}]^{+}} \\
\left(\mathrm{CF}_{3} \mathrm{CCCF}_{3}\right)\end{array}$ & $\begin{array}{c}{[\mathrm{Au}]^{+}} \\
\left(\mathrm{CF}_{3} \mathrm{CCCF}_{3}\right)\end{array}$ & $\begin{array}{c}{[\mathrm{Au}]^{+}} \\
(\mathrm{PhCCPh})\end{array}$ & $\begin{array}{c}{[\mathrm{Au}]^{+}} \\
(\mathrm{MeCCMe})\end{array}$ & $\begin{array}{c}{[\mathrm{Au}]^{+}} \\
\left(\mathrm{CF}_{3} \mathrm{CCCF}_{3}\right)\end{array}$ \\
\hline Frag2 & & {$[\mathrm{Au}] \mathrm{OMe}$} & $1 \mathrm{MeOH}$ & $2 \mathrm{MeOH}$ & $1 \mathrm{MeOH}$ & $2 \mathrm{MeOH}$ & $1 \mathrm{MeOH}$ & $2 \mathrm{MeOH}$ & {$[\mathrm{Au}] \mathrm{OPh}$} & $2 \mathrm{PhOH}$ & $2 \mathrm{PhOH}$ \\
\hline \multirow[t]{4}{*}{$\mathrm{RC}$} & $\Delta \mathrm{E}_{\text {def }}($ Frag1) & 3.26 & 2.98 & 3.61 & 0.70 & 1.03 & 0.10 & 2.40 & 0.89 & 2.22 & 2.70 \\
\hline & $\Delta \mathrm{E}_{\text {def }}$ & 4.84 & 2.99 & 6.01 & 0.72 & 2.14 & 0.14 & 3.41 & 1.39 & 15.67 & 5.19 \\
\hline & $\Delta \mathrm{E}_{\text {int }}$ & -1.23 & 4.80 & 0.44 & 5.96 & 2.63 & 4.39 & 0.04 & -1.45 & -9.87 & 0.21 \\
\hline & $\mathrm{BE}$ & 3.61 & 7.79 & 6.45 & 6.63 & 4.76 & 4.53 & 3.45 & -0.06 & 5.80 & 5.40 \\
\hline \multirow[t]{5}{*}{ TS } & $\Delta \mathrm{E}_{\text {def }}($ Frag 1$)$ & 7.14 & 29.72 & 15.33 & 21.26 & 17.31 & 9.64 & 9.64 & 15.54 & 25.19 & 9.95 \\
\hline & $\Delta \mathrm{E}_{\text {def }}($ Frag2) & 1.46 & 1.11 & 2.63 & 0.99 & 2.94 & 1.18 & 2.37 & 0.93 & 20.37 & 2.69 \\
\hline & $\Delta \mathrm{E}_{\text {def }}$ & 8.60 & 30.83 & 17.96 & 22.24 & 20.25 & 10.82 & 12.01 & 16.46 & 45.56 & 12.64 \\
\hline & $\Delta \mathrm{E}_{\text {int }}$ & -2.63 & -3.99 & -0.31 & 2.32 & -1.98 & 6.93 & -1.40 & -9.02 & -16.00 & 0.73 \\
\hline & $\mathrm{BE}$ & 5.97 & 26.84 & 17.65 & 24.56 & 18.27 & 17.75 & 10.62 & 7.44 & 29.56 & 13.37 \\
\hline \multicolumn{2}{|c|}{ VE interm $\Delta \mathrm{E}_{\text {def }}$ (Frag1) } & 51.87 & 40.42 & 45.85 & 45.80 & 49.55 & 51.40 & 52.36 & 48.90 & 45.25 & 52.18 \\
\hline & $\Delta \mathrm{E}_{\text {def }}($ Frag2) & 6.02 & 2.04 & 10.94 & 3.72 & 24.26 & 4.60 & 24.08 & 6.21 & 10.96 & 24.89 \\
\hline & $\Delta \mathrm{E}_{\text {def }}$ & 57.89 & 42.46 & 56.79 & 49.52 & 73.81 & 56.00 & 76.43 & 55.11 & 56.20 & 77.07 \\
\hline & $\Delta \mathrm{E}_{\text {int }}$ & -68.47 & -14.61 & -38.25 & -25.87 & -59.89 & -49.72 & -86.78 & -57.50 & -26.59 & -74.46 \\
\hline
\end{tabular}

For dimethylacetylene, Table 1 confirms that dual gold catalysis lowers the energy barrier for the $\mathrm{C}-\mathrm{O}$ bond formation by 11.68 $\mathrm{kcal} \mathrm{mol}{ }^{-1}$ when compared to the mono gold path. On the other hand, we found that fluoride substituted alkynes facilitate $\mathrm{C}-\mathrm{O}$ bond formation by increasing the electrophilicity of the fragment, in particular, the positive charge on the carbon atoms of the former alkyne. BEs at the TS show rather large energy barriers in monogold electrophile/nucleophile interaction, being kinetically unfavorable in contrast to the digold mechanism ones. Ultimately, diphenylacetylene is more favored than dimethylacetylene (vide infra).

When changing the nature of the alcohol, from alkylic to arylic alcohols, i.e. from $\mathrm{MeOH}$ to $\mathrm{PhOH}$ (Table 1) we observe that the higher acidity of the phenol increases the activation energy of monogold fluoride substituted alkyne system by $2.75 \mathrm{kcal} \mathrm{mol}^{-1}$, whereas the dual gold pathway is slightly more energetic by 1.47

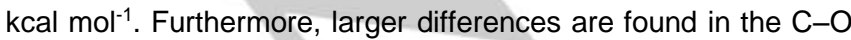
bond stability. This reaction is thermodynamically favored through dual activation gold catalysis. Systems here probe the inherent low basicity of the phenol to promote the nucleophilic attack.

Among the alkynes used in the monometallic catalytic system, the diphenylacetylene is slightly more favored kinetically and thermodynamically than dimethylacetylene. The results shown in Table 1 suggest that the trifluoromethyl leads a much more facile phenoxylation. The reason for such behavior is the more positive charge held on the carbon atoms of the former alkyne, thus becoming a better electrophile. Likewise, the gold(I)-phenoxide might not be as good nucleophile as the gold(I)-methoxy moiety in the dual gold activation mechanism. Furthermore, it is shown that phenol is not as good nucleophile as methanol, due to the different acidic character of both alcohols $\left(\mathrm{pK}_{\mathrm{a}}=9.98\right.$ and 15.50, respectively).$^{[47]}$ The energy barrier for the dual metal mechanism drops by at least $10 \mathrm{kcal} \mathrm{mol}^{-1}$ compared to the mono metal path (Table 1). In conclusion, without the second gold moiety activating the Lewis acid fragment, this step does not proceed favorably, even in the systems where fluoride substituents on the alkyne may increase the electron-deficient character at the carbon atoms to facilitate the $\mathrm{C}-\mathrm{O}$ bond formation. Overall, it is confirmed the feasibility of two relatively different reactions (i.e. using either the alkoxide or the alcohol as a nucleophile), in which the BellEvans-Polanyi principle applies here, correlating the difference in activation energy to the difference of Gibbs energy of reaction $\left(R^{2}\right.$ $=0.91) \cdot{ }^{[48,49]}$ 
Hereunder, we used Mayer Bond Orders (MBOs) to better understand the evolution of the $\mathrm{C} \equiv \mathrm{C}$ bond as the reaction proceeds and the $\mathrm{C}-\mathrm{O}$ bond formation takes place. ${ }^{[50,51]} \mathrm{MBO}$ for the $\mathrm{C} \equiv \mathrm{C}$ in methyl and phenyl substituted alkynes are shown in Table 2, with methanol as a nucleophile. It may be observed that the $\mathrm{C} \equiv \mathrm{C}$ bond in $[\mathrm{Au}]^{+}(\mathrm{Me}-\mathrm{CC}-\mathrm{Me})$ does not change considerably when comparing the RC with the VE intermediate, pointing out that this bond is already activated by $A u$ in the $R C$ intermediate. Interestingly, at the TS structure the $C \equiv C M B O$ is almost identical for both alkynes. The main result that arises from inspection of MBOs is that the alkoxylation process is more favored for the diphenylacetylene over the dimethylacetylene due to the weaker $\mathrm{C} \equiv \mathrm{C}$ bond in the former $(\mathrm{MBO}=1.76)$ compared to $[\mathrm{Au}]^{+}(\mathrm{Me}-\mathrm{CC}-\mathrm{Me})(\mathrm{MBO}=1.97)$.

Table 2. Mayer bond orders for the $\mathrm{C} \equiv \mathrm{C}$ of different alkynes activated by gold as the VE intermediate is being formed $(R C=$ reactant complex; TS $=$ transition state; VE interm $=$ vinyl ether intermediate; $[\mathrm{Au}]=\mathrm{Au}(\mathrm{IMe}))$.

\begin{tabular}{cccc}
\hline Species & RC & TS & VE interm \\
\hline$[\mathrm{Au}]^{+}(\mathrm{Ph}-\mathrm{CC}-\mathrm{Ph})+\mathrm{MeOH}$ & 1.76 & 2.04 & 1.82 \\
{$[\mathrm{Au}]^{+}(\mathrm{Me}-\mathrm{CC}-\mathrm{Me})+\mathrm{MeOH}$} & 1.97 & 2.01 & 1.93 \\
\hline
\end{tabular}

Finally, the lower the MBO of the former $\mathrm{C} \equiv \mathrm{C}$ bond, the easier for the alcoholic species to attack it and form the VE intermediate.

To support the above statements, an energy decomposition analysis (EDA) was carried out using the ADF package. By omitting the thermal contributions, we focus on the electronic contributions in the interaction energy of the CC bond, which enables a quantitative analysis of the nature of this bond. The interaction energy is decomposed in its components, i.e. Pauli repulsion $\left(\Delta \mathrm{E}_{\text {pauil }}\right)$, orbital interaction $\left(\Delta \mathrm{E}_{\mathrm{oi}}\right)$, electrostatic $\left(\Delta \mathrm{E}_{\text {elst }}\right)$, and dispersion $\left(\Delta \mathrm{E}_{\text {disp }}\right)$ (see Experimental section). In our case, the $\Delta \mathrm{E}_{\text {elst }}$ term is very relevant and will help us to quantify the coulombic interaction between the two moieties. Table 3 gathers the results of the EDA. Despite the effect of the omission of the thermal contribution may cause, this analysis is helpful to compare the interactions among the different catalytic systems. The fragment interaction keeps growing until the $\mathrm{C}-\mathrm{O}$ bond is formed, as well as the favorable orbital interaction and electrostatic components. The $\Delta \mathrm{E}_{\mathrm{oi}}$ term experiments the largest change along the reaction, which is compensated to some extent by the repulsive Pauli contribution.

Table 3. EDA for the interaction energies for the nucleophilic C-O bond formation aforementioned with methanol/methoxide and phenol/phenoxide (relative energies in $\mathrm{kcal} \mathrm{mol}^{-1}$ with respect to both separated fragments, in $\left.\mathrm{kcal} \mathrm{mol}^{-1}\right)$. $(\mathrm{RC}=$ reactant complex; TS $=$ transition state; VE interm $=$ vinyl ether intermediate; $[\mathrm{Au}]=\mathrm{Au}(\mathrm{IMe})$ )

\begin{tabular}{|c|c|c|c|c|c|c|c|}
\hline Species & & State & $\Delta \mathrm{E}_{\text {Pauli }}$ & $\Delta \mathrm{E}_{\text {elst }}$ & $\Delta \mathrm{E}_{\mathrm{oi}}$ & $\Delta \mathrm{E}_{\text {disp }}$ & $E$ \\
\hline $\mathrm{NHC}$ & $\mathrm{IMe}$ & $\mathrm{RC}$ & 21.59 & -22.23 & -14.57 & -3.16 & -18.37 \\
\hline Frag1 & {$[\mathrm{Au}]^{+}(\mathrm{Me}-\mathrm{CC}-\mathrm{Me})$} & TS & 18.41 & -21.80 & -12.05 & -6.42 & -21.86 \\
\hline Frag2 & [Au]OMe & VE interm & 269.28 & -152.04 & -195.98 & -8.73 & -87.47 \\
\hline $\mathrm{NHC}$ & $\mathrm{IMe}$ & $\mathrm{RC}$ & 4.62 & -6.53 & -2.06 & -2.26 & -6.23 \\
\hline Frag1 & {$[\mathrm{Au}]^{+}(\mathrm{Me}-\mathrm{CC}-\mathrm{Me})$} & TS & 119.01 & -62.01 & -74.22 & -4.66 & -21.88 \\
\hline Frag2 & $1 \mathrm{MeOH}$ & VE interm & 187.65 & -93.25 & -120.73 & -4.72 & -31.05 \\
\hline $\mathrm{NHC}$ & $\mathrm{IMe}$ & $\mathrm{RC}$ & 6.18 & -10.53 & -3.30 & -2.79 & -10.44 \\
\hline Frag1 & {$[\mathrm{Au}]^{+}(\mathrm{Me}-\mathrm{CC}-\mathrm{Me})$} & TS & 42.64 & -29.68 & -25.51 & -5.63 & -18.18 \\
\hline Frag2 & $2 \mathrm{MeOH}$ & VE interm & 228.63 & -125.50 & -152.78 & -7.16 & -56.81 \\
\hline Frag1 & {$[\mathrm{Au}]^{+}(\mathrm{Ph}-\mathrm{CC}-\mathrm{Ph})$} & TS & 81.73 & -43.72 & -48.62 & -7.04 & -17.65 \\
\hline Frag2 & $1 \mathrm{MeOH}$ & VE interm & 245.23 & -122.75 & -156.57 & -7.65 & -41.74 \\
\hline $\mathrm{NHC}$ & $\mathrm{IMe}$ & $\mathrm{RC}$ & 10.12 & -11.81 & -5.18 & -3.37 & -10.24 \\
\hline Frag1 & {$[\mathrm{Au}]^{+}(\mathrm{Ph}-\mathrm{CC}-\mathrm{Ph})$} & TS & 55.23 & -33.27 & -31.61 & -8.74 & -18.39 \\
\hline Frag2 & $2 \mathrm{MeOH}$ & VE interm & 321.76 & -169.55 & -219.70 & -11.96 & -79.45 \\
\hline $\mathrm{NHC}$ & $\mathrm{IMe}$ & $\mathrm{RC}$ & 7.75 & -8.78 & -2.47 & -3.17 & -6.67 \\
\hline Frag1 & {$[\mathrm{Au}]^{+}\left(\mathrm{CF}_{3}-\mathrm{CC}-\mathrm{CF}_{3}\right)$} & TS & 35.76 & -21.73 & -17.23 & -4.92 & -8.12 \\
\hline Frag2 & $1 \mathrm{MeOH}$ & VE interm & 291.94 & -148.29 & -203.77 & -5.15 & -65.27 \\
\hline $\mathrm{NHC}$ & $\mathrm{IMe}$ & $\mathrm{RC}$ & 11.33 & -14.21 & -4.42 & -4.14 & -11.44 \\
\hline Frag2 & $2 \mathrm{MeOH}$ & VE interm & 316.34 & -178.00 & -231.39 & -7.44 & -100.49 \\
\hline $\mathrm{NHC}$ & $\mathrm{IMe}$ & $\mathrm{RC}$ & 11.44 & -15.95 & -6.98 & -12.09 & -23.58 \\
\hline Frag1 & {$[\mathrm{Au}]^{+}(\mathrm{Ph}-\mathrm{CC}-\mathrm{Ph})$} & TS & 49.35 & -33.36 & -31.70 & -18.64 & -34.35 \\
\hline Frag2 & {$[\mathrm{Au}] \mathrm{OPh}$} & VE interm & 316.49 & -165.55 & -212.16 & -19.08 & -80.30 \\
\hline $\mathrm{NHC}$ & $\mathrm{IMe}$ & $\mathrm{RC}$ & 4.62 & -6.53 & -2.06 & -2.26 & -8.87 \\
\hline Frag1 & {$[\mathrm{Au}]^{+}(\mathrm{Me}-\mathrm{CC}-\mathrm{Me})$} & TS & 88.14 & -49.27 & -56.97 & -8.66 & -26.76 \\
\hline Frag2 & $2 \mathrm{PhOH}$ & VE interm & 225.98 & -117.33 & -150.40 & -9.05 & -50.80 \\
\hline $\mathrm{NHC}$ & $\mathrm{IMe}$ & $\mathrm{RC}$ & 10.54 & -11.35 & -5.88 & -10.67 & -17.36 \\
\hline Frag1 & {$[\mathrm{Au}]^{+}\left(\mathrm{CF}_{3}-\mathrm{CC}-\mathrm{CF}_{3}\right)$} & TS & 25.07 & -18.42 & -15.26 & -8.75 & -17.36 \\
\hline Frag2 & $2 \mathrm{PhOH}$ & VE interm & 317.86 & -168.83 & -233.30 & -9.75 & -94.02 \\
\hline
\end{tabular}

From Table 3, it may be observed that the most stabilizing interaction energy was obtained for di(trifluoromethyl)acetylene. This trend can be understood since in di(trifluoromethyl)acetylene the CC bond is poorer in electron density due to the electron- withdrawing nature of the $-\mathrm{CF}_{3}$ groups. The $[\mathrm{Au}]^{+}\left(\mathrm{CF}_{3}-\mathrm{CC}-\mathrm{CF}_{3}\right)$ system (with $[\mathrm{Au}]=\mathrm{Au}(\mathrm{IMe}))$ is by $34.22(1 \mathrm{MeOH})$ and $43.68 \mathrm{kcal}$ $\mathrm{mol}^{-1}(2 \mathrm{MeOH})$ more stable than reactions using $[\mathrm{Au}]^{+}\left(\mathrm{CH}_{3}-\mathrm{CC}-\right.$ $\left.\mathrm{CH}_{3}\right)$, and $23.53(1 \mathrm{MeOH})$ and $21.04 \mathrm{kcal} \mathrm{mol}^{-1}(2 \mathrm{MeOH})$ more 
stable than $[\mathrm{Au}]^{+}(\mathrm{Ph}-\mathrm{CC}-\mathrm{Ph})$ in the VE intermediate. For instance, with two methanol units, mostly the fluorinated system shows higher interaction energy of $43.68 \mathrm{kcal} \mathrm{mol}^{-1}$ than the homologous non fluorinated system due to the orbital interaction term (-78.61 $\left.\mathrm{kcal} \mathrm{mol}^{-1}\right)$, that is larger than the electrostatic contribution $(-52.50$ $\left.\mathrm{kcal} \mathrm{mol}^{-1}\right)$, but compensating both together significantly the increase of Pauli repulsion $\left(87.86 \mathrm{kcal} \mathrm{mol}^{-1}\right)$. Thus, inclusion of $\mathrm{CF}_{3}$ groups is preferred by allowing a thermodynamically more favorable way toward the $\mathrm{C}-\mathrm{O}$ bond formation. Inspection of the frontier molecular orbitals of $[\mathrm{Au}]^{+}\left(\mathrm{CH}_{3}-\mathrm{CC}-\mathrm{CH}_{3}\right)$ shows that the energy of the LUMO orbital of the cationic gold-alkyne moiety is lowered by fluorination and makes it more accessible to the oxygen. In Figure S1 (see SI), we observe that the LUMO is formed mainly by the cationic $\pi$-gold-alkyne, whereas the HOMO belongs to the alcoholic part. Moreover, dual gold activation has more favorable electrostatic and orbital interactions and, although both attractive contributions are slightly lower for the transition state, the overall interaction is the most favorable. The reason is found in the destabilizing Pauli term that increases from 18.41 $\mathrm{kcal} \mathrm{mol}{ }^{-1}$ for the bimetallic to $42.64 \mathrm{kcal} \mathrm{mol}^{-1}$ for the monometallic. More importantly, in the intermediate with the formed $\mathrm{C}-\mathrm{O}$ bond, the stabilizing 43.20 and $26.54 \mathrm{kcal} \mathrm{mol}^{-1}$ of the orbital and electrostatic contributions are determinant, because they compensate by far the unfavorable $40.65 \mathrm{kcal} \mathrm{mol}^{-}$ 1 of the Pauli term, with the resulting increase of the interaction energy by $30.66 \mathrm{kcal} \mathrm{mol}^{-1}$. This agrees with the mentioned dual functionality in digold complexes where we stablished the Lewis acidic fragment to be the cationic fragment and the alkoxide to behave as a Brønsted base.

With respect to phenol/phenoxide in Table 3, the best result at the TS we got is for the cooperative two gold system again, being it almost twice favorable with respect to the monometallic system bearing the phenyl substituted alkyne $\left(29.5 \mathrm{kcal} \mathrm{mol}^{-1}\right)$. As above stated, the phenol fragment is less nucleophilic than methanol and accordingly the interaction energy with two alcohol moieties is $6.01 \mathrm{kcal} \mathrm{mol}^{-1}$ less stable for the phenol than the methanol due to the electrostatic loss of $8.17 \mathrm{kcal} \mathrm{mol}^{-1}$.

The comparative analysis of the $\mathrm{C}-\mathrm{O}$ bond formation in monogold catalysis with respect to the digold activated one helped us to quantitatively define the preference in the generation of VE intermediate through the BEs. Thus, in order to optimize the process we focused the efforts on the bimetallic cooperative $\mathrm{C}-\mathrm{O}$ bond formation and, to do so, other metals holding similar properties to gold like copper ${ }^{[35]}$ and silver are tested as they are able to form the same complexes with alkyne and alcohol substrates. ${ }^{[39]}$

The $\mathrm{C}-\mathrm{O}$ bond formation for the phenoxylation of diphenylacetylene with a dual metal character was explored. Homobimetallic systems including two same group 11 metals (M), and also heterobimetallic with its combinations, are tested in order to discover how the $\mathrm{C}-\mathrm{O}$ bond formation is affected by changing the metal and compare the capability of each metal. Bearing in mind that gem-dimetal hydroxydes and phenoxides equilibrate to play the role of pre-catalysts, here we focus again in the neutral phenoxide ([M(OPh)(IPr)]) and cationic ([M(Ph-CC-Ph)(IPr) $\left.]^{+}\right)$ moieties that conduct the reaction of the $\mathrm{C}-\mathrm{O}$ bond formation. Besides, we denote the use of the IPr as a larger NHC ligand than $\mathrm{IMe}$, and more constrained in the first metal sphere, according to $\% \mathrm{~V}_{\text {Bur }}$ values $(33.6 \% \text { vs } 24.9 \%)^{[52,53,54]}$ Table 4 collects the energy barriers and the thermodynamic stabilization of this step.

Table 4. Influence of the [M]-IPr catalyst in the C-O bond formation, EDA, relative energies (in kcal mol ${ }^{-1}$ ) with respect to both separated fragments for the homobimetallic and heterobimetallic systems in dual catalysis. Energies are reported in kcal mol ${ }^{-1}(T S=$ transition state; VE interm = vinyl ether intermediate, $[\mathrm{M}]=\mathrm{M}(\mathrm{IPr})$, Frag1 $=[\mathrm{M}(\mathrm{Ph}-\mathrm{CC}-\mathrm{Ph})(\mathrm{IPr})]^{+}$, Frag2 $=[\mathrm{M}(\mathrm{OPh})(\mathrm{IPr})]$ with $\left.\mathrm{M}=\mathrm{Cu}, \mathrm{Ag}, \mathrm{Au}\right)$.

\begin{tabular}{|c|c|c|c|c|c|c|c|}
\hline Frag1 & & {$[\mathrm{Au}]^{+}(\mathrm{Ph}-\mathrm{CC}-\mathrm{Ph})$} & {$[\mathrm{Au}]^{+}(\mathrm{Ph}-\mathrm{CC}-\mathrm{Ph})$} & {$[\mathrm{Au}]^{+}(\mathrm{Ph}-\mathrm{CC}-\mathrm{Ph})$} & {$[\mathrm{Cu}]^{+}(\mathrm{Ph}-\mathrm{CC}-\mathrm{Ph})$} & {$[\mathrm{Cu}]^{+}(\mathrm{Ph}-\mathrm{CC}-\mathrm{Ph})$} & {$[\mathrm{Ag}]^{+}(\mathrm{Ph}-\mathrm{CC}-\mathrm{Ph})$} \\
\hline Frag2 & & $\mathrm{Au}-\mathrm{OPh}$ & $\mathrm{Cu}-\mathrm{OPh}$ & $\mathrm{Ag}-\mathrm{OPh}$ & $\mathrm{Au}-\mathrm{OPh}$ & $\mathrm{Cu}-\mathrm{OPh}$ & $\mathrm{Ag}-\mathrm{OPh}$ \\
\hline \multirow[t]{4}{*}{ TS } & $\Delta \mathrm{E}_{\text {def }}($ Frag1) & 17.02 & 15.67 & 14.27 & 22.90 & 22.71 & 18.30 \\
\hline & $\Delta \mathrm{E}_{\text {def }}($ Frag2) & 3.18 & 3.04 & 5.33 & 4.65 & 4.61 & 4.68 \\
\hline & $\Delta \mathrm{E}_{\text {int }}$ & -5.39 & -5.80 & -9.40 & -8.65 & -8.91 & -6.60 \\
\hline & $B E$ & 14.81 & 12.91 & 10.20 & 18.90 & 18.40 & 16.37 \\
\hline \multirow[t]{4}{*}{ VE interm } & $\Delta \mathrm{E}_{\text {def }}($ Frag 1$)$ & 51.44 & 51.52 & 51.20 & 54.62 & 54.78 & 48.98 \\
\hline & $\Delta \mathrm{E}_{\text {def }}$ & 62.19 & 61.50 & 60.34 & 61.52 & 63.43 & 55.23 \\
\hline & $\Delta \mathrm{E}_{\text {int }}$ & -61.47 & -63.68 & -64.91 & -52.53 & -59.33 & -53.85 \\
\hline & $\mathrm{BE}$ & 0.72 & -2.18 & -4.57 & 8.99 & 4.09 & 1.38 \\
\hline
\end{tabular}

According to the information in Table 4, homobimetallic systems with copper and silver generate the VE intermediates more unfavorably than the digold system by $3.37 \mathrm{kcal} \mathrm{mol}^{-1}$ and 0.66 $\mathrm{kcal} \mathrm{mol}{ }^{-1}$, respectively. Furthermore, the energy barriers for the digold system are lower by 3.59 and $1.56 \mathrm{kcal} \mathrm{mol}^{-1}$ than the copper and silver derivatives, respectively. And Cudiphenylacetylene/Au-phenoxide system shows the most unfavorable combination among all the heterobimetallic systems studied here, which confirms that the gold phenoxide fragment is not a good nucleophile. However, heterobimetallic systems conformed by $\mathrm{Au}$-diphenylacetylene and $\mathrm{Cu} / \mathrm{Ag}$-phenoxide excel in the $\mathrm{C}-\mathrm{O}$ bond formation because the energy needed to construct it is lowered by $1.90 \mathrm{kcal} \mathrm{mol}^{-1}$ and $4.61 \mathrm{kcal} \mathrm{mol}^{-1}$, respectively, compared to that of the previously explored digold system. In addition, the thermodynamics also confirm those results as the coupling is 2.90 and $5.29 \mathrm{kcal} \mathrm{mol}^{-1}$ more stable, respectively, and even this step becomes exergonic by 2.18 and $4.57 \mathrm{kcal} \mathrm{mol}^{-1}$. The detail in the decomposition into deformation 
and interaction energies unveils that the argentum fragment with the alkyne is less affected than $\mathrm{Au}$ or $\mathrm{Cu}$ ones, while the main difference comes from the interaction energy. In particular, it follows the trend $\mathrm{Au}<\mathrm{Cu}<\mathrm{Ag}$, being for the $\mathrm{Cu}$ and $\mathrm{Ag}$ systems 0.41 and $4.01 \mathrm{kcal} \mathrm{mol}^{-1}$ higher than for $\mathrm{Au}$; and the same applies for the next intermediate, with larger values by 2.21 and $3.44 \mathrm{kcal}$ $\mathrm{mol}^{-1}$, respectively.

As pointed out above, the results in Table 1 for the digold catalysis gave more favorable results for the formation of the $\mathrm{C}$ $O$ bond. Actually, the energy barrier turns out to be $7.37 \mathrm{kcal} \mathrm{mol}^{-}$ ${ }^{1}$ higher than the previous result displayed in Table 1 with the similar system Au-diphenylacetylene/Au-phenoxide. The reason is that complexes bearing IMe instead of the IPr NHC ligand form the $\mathrm{C}-\mathrm{O}$ bond in a rather more facile way. It can be appreciated that larger NHC ligands entail higher energy barriers as well as less stable VE intermediate when the $\mathrm{C}-\mathrm{O}$ bond is formed.

Table 5 encloses the EDA data computed for the combinations included in Table 4. We can observe that the kinetics and thermodynamics follow a similar behaviour to what we depicted in Table 3. Specifically, the EDA is not that interesting here for the kinetics formulated by the TS, but the thermodynamics defined by the VE intermediate. For the latter species, the trend is perfectly defined by the VE intermediate when going from AuOPh $(86.62$ kcal mol$\left.{ }^{-1}\right)$ to AgOPh $\left(92.45 \mathrm{kcal} \mathrm{mol}^{-1}\right)$, with CuOPh (89.03 kcal $\mathrm{mol}^{-1}$ ) in between, thus confirming that it is following the expected sequence $\mathrm{Au} \rightarrow \mathrm{Cu} \rightarrow \mathrm{Ag}$, despite not including the entropy and thermal corrections like in Table 3. To find out which is the term responsible for the electronic behaviour is not trivial and the EDA is fundamental to clearly distinguish the key factors. It could be considered a combination of factors, since mostly the orbital interactions are favored for $\mathrm{Ag}$ rather than for $\mathrm{Cu}$ or $\mathrm{Au}$ by 6.69 and $10.34 \mathrm{kcal} \mathrm{mol}^{-1}$, respectively; when the electrostatic term also increases by 4.22 and $6.89 \mathrm{kcal} \mathrm{mol}^{-1}$; whereas the unfavorable Pauli term partially compensates the favored behavior for $\mathrm{Ag}$ since it favors $\mathrm{Ag}$ over $\mathrm{Cu}$ and $\mathrm{Au}$ by 5.17 and $9.76 \mathrm{kcal} \mathrm{mol}^{-1}$, respectively.

Table 5. EDA for the interaction energies obtained for the homobimetallic and heterobimetallic systems in dual catalysis (relative energies with respect to both separated fragments calculated with the ADF program in $\mathrm{kcal} \mathrm{mol}^{-1}$ ).

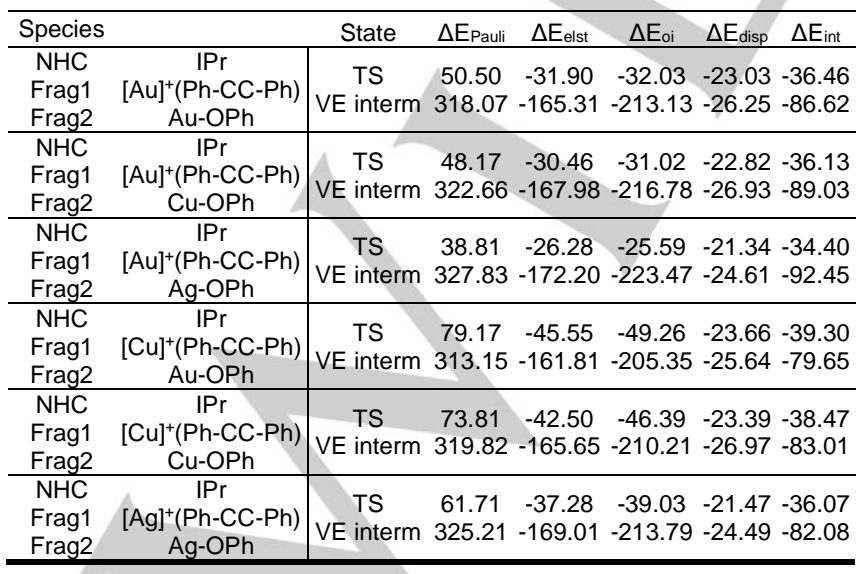

This last speciation stands out the different capability of each metal to activate the substrates in a different way and, while copper or silver cannot be compared to gold at increasing the electrophilicity of the alkyne substrate, the opposite effect is found for gold at the nucleophilic character of the alkoxide fragment.

Mayer Bond Orders (MBO) of the previous homobimetallic and heterometallic systems with group 11 metals confirm that the gold achieves a better activation of the alkyne compound in comparison with silver. Nevertheless, copper holds higher MBOs than gold does, which means that copper is also good at activating the alkyne moiety (Table 6).

Table 6. MBO index for metal-carbon (M-C) and metal-oxygen (M-O) bonds on both free fragments (Free), transition state (TS) and intermediate (Int) for bimetallic systems $([\mathrm{Au}]=\mathrm{Au}(\mathrm{IPr}))$.

\begin{tabular}{cccccc}
\hline Fragment & & Bond & Free & TS & Int \\
\hline Frag1 & {$[\mathrm{Au}]^{+}(\mathrm{Ph}-\mathrm{CC}-\mathrm{Ph})$} & $\mathrm{Au}-\mathrm{C}$ & 0.448 & 0.558 & 0.726 \\
Frag2 & $\mathrm{Au}-\mathrm{OPh}$ & $\mathrm{Au}-\mathrm{O}$ & 0.814 & 0.601 & 0.391 \\
Frag1 & {$[\mathrm{Au}]^{+}(\mathrm{Ph}-\mathrm{CC}-\mathrm{Ph})$} & $\mathrm{Au}-\mathrm{C}$ & 0.448 & 0.556 & 0.723 \\
Frag2 & $\mathrm{Cu}-\mathrm{OPh}$ & $\mathrm{Cu}-\mathrm{O}$ & 0.894 & 0.671 & 0.430 \\
Frag1 & {$[\mathrm{Au}]^{+}(\mathrm{Ph}-\mathrm{CC}-\mathrm{Ph})$} & $\mathrm{Au}-\mathrm{C}$ & 0.448 & 0.628 & 0.785 \\
Frag2 & $\mathrm{Ag}-\mathrm{OPh}$ & $\mathrm{Ag}-\mathrm{O}$ & 0.818 & 0.559 & 0.397 \\
Frag1 & {$[\mathrm{Cu}]^{+}(\mathrm{Ph}-\mathrm{CC}-\mathrm{Ph})$} & $\mathrm{Cu}-\mathrm{C}$ & 0.451 & 0.619 & 0.783 \\
Frag2 & $\mathrm{Au}-\mathrm{OPh}$ & $\mathrm{Au}-\mathrm{O}$ & 0.814 & 0.628 & 0.437 \\
Frag1 & {$[\mathrm{Cu}]^{+}(\mathrm{Ph}-\mathrm{CC}-\mathrm{Ph})$} & $\mathrm{Cu}-\mathrm{C}$ & 0.451 & 0.547 & 0.726 \\
Frag2 & $\mathrm{Cu}-\mathrm{OPh}$ & $\mathrm{Cu}-\mathrm{O}$ & 0.894 & 0.607 & 0.356 \\
Frag1 & {$[\mathrm{Ag}]^{+}(\mathrm{Ph}-\mathrm{CC}-\mathrm{Ph})$} & $\mathrm{Ag}-\mathrm{C}$ & 0.341 & 0.525 & 0.699 \\
Frag2 & $\mathrm{Ag}-\mathrm{OPh}$ & $\mathrm{Ag}-\mathrm{O}$ & 0.818 & 0.563 & 0.361 \\
\hline
\end{tabular}

It is important to note that as the fragments start interacting and getting closer to each other, the bond strength of the $\mathrm{M}-\mathrm{C}(\mathrm{Ph})$ bond goes from being the same with both carbon atoms of the alkyne to a sharp decrease in the case of the carbon atom that takes part in the formation of the $\mathrm{C}-\mathrm{O}$ bond. As a consequence, the strength of the bond with the participation of the "inert" carbon attached to the metal increases accordingly. At the same time, the strength of the $\mathrm{M}-\mathrm{O}(\mathrm{Ph})$ bond decreases while the $\mathrm{C}-\mathrm{O}$ bond is being formed. Even though Table 6 states that copper activates both fragments better, with the information of the strength that holds the $\mathrm{C}-\mathrm{O}$ bond on its formation step, Table 7 shows that when the gold-alkyne fragment is considered, any of the three combinations unveil that the $\mathrm{MBO}$ of the $\mathrm{C}-\mathrm{O}$ bond is relatively higher, thus making a stronger bond between the two fragments and, consequently, a more stable intermediate, compared to either the copper or argentum-alkyne fragment.

Table 7. MBO index for the $\mathrm{C}-\mathrm{C}$ and $\mathrm{C}-\mathrm{O}$ bonds on the free alkyne-metal cationic fragment (Free), transition state (TS) and intermediate (Int) for bimetallic systems $(\mathrm{Au}=\mathrm{Au}(\mathrm{IPr}))$.

\begin{tabular}{ccccc}
\hline Species & Bond & Free & TS & Int \\
\hline$[\mathrm{Au}]^{+}(\mathrm{PhCCPh})$ & $\mathrm{C}-\mathrm{C}$ & 1.704 & 2.085 & 1.770 \\
{$[\mathrm{Ag}]^{+}(\mathrm{PhCCPh})$} & $\mathrm{C}-\mathrm{C}$ & 1.870 & 2.134 & 1.809 \\
{$[\mathrm{Cu}]^{+}(\mathrm{PhCCPh})$} & $\mathrm{C}-\mathrm{C}$ & 1.686 & 1.996 & 1.800 \\
{$[\mathrm{Au}(\mathrm{OPh})-\mathrm{Au}(\mathrm{PhCCPh})]^{+}$} & $\mathrm{C}-\mathrm{O}$ & - & 0.240 & 0.791 \\
{$[\mathrm{Cu}(\mathrm{OPh})-\mathrm{Au}(\mathrm{PhCCPh})]^{+}$} & $\mathrm{C}-\mathrm{O}$ & - & 0.237 & 0.785 \\
{$[\mathrm{Au}(\mathrm{OPh})-\mathrm{Cu}(\mathrm{PhCCPh})]^{+}$} & $\mathrm{C}-\mathrm{O}$ & - & 0.336 & 0.763 \\
{$[\mathrm{Cu}(\mathrm{OPh})-\mathrm{Cu}(\mathrm{PhCCPh})]^{+}$} & $\mathrm{C}-\mathrm{O}$ & - & 0.326 & 0.758 \\
{$[\mathrm{Ag}(\mathrm{OPh})-\mathrm{Au}(\mathrm{PhCCPh})]^{+}$} & $\mathrm{C}-\mathrm{O}$ & - & 0.192 & 0.826 \\
{$[\mathrm{Ag}(\mathrm{OPh})-\mathrm{Ag}(\mathrm{PhCCPh})]^{+}$} & $\mathrm{C}-\mathrm{O}$ & - & 0.291 & 0.806 \\
\hline
\end{tabular}


To complement the previous information, we show the MBO of the $\mathrm{C}-\mathrm{C}$ bond of the alkyne in the systems bearing different metals. The trend is that the bond strength decreases from the TS to the intermediate to result in a similar MBO to that of the free fragments. Thus, the TS is closer to the alkyne character. And as the $\mathrm{C}-\mathrm{O}$ bond is being formed, the $\mathrm{C}-\mathrm{C}$ bond strength decreases, as expected. However, and more importantly, the copper is able to activate slightly more the $\mathrm{C}-\mathrm{C}$ bond with $\mathrm{Cu}$ rather than $\mathrm{Au}$, and more significantly with respect to $\mathrm{Ag}$.

All in all, even though the Au-diphenylacetylene/Ag-phenoxide combination is slightly better than for Au-diphenylacetylene/Cu- phenoxide according to the data in Table 4, the latter system to get VE intermediates with CUOPh moiety as the nucleophile shows good affinity for the electrophile at the $\mathrm{C}-\mathrm{O}$ bond formation, with favorable kinetics and thermodynamics in Table 5 and mainly in Table 4. Additionally, Tables 6 and 7 show that copper is a fairly good activator and gold generates a strong $\mathrm{C}-\mathrm{O}$ bond, anyway always better than with the digold system. Since copper is an earth abundant element and it is the cheapest of group 11 here, and it has been tested experimentally yet, ${ }^{[35]}$ we chose it to test the sterical hindrance of the NHC ligand (Table 8).

Table 8. Copper and gold heterodual catalysed C-O bond formation (relative Gibbs energies with respect to both separated fragments in $\mathrm{kcal} \mathrm{mol}^{-1}$ ).

\begin{tabular}{|c|c|c|c|c|c|c|}
\hline $\mathrm{NHC}$ & & IMes & SIMes & $\mathrm{IMe}$ & $\mathrm{IPr}$ & $\mathrm{IPr}^{*}$ \\
\hline Frag1 & & {$[\mathrm{Au}]^{+}(\mathrm{Ph}-\mathrm{CC}-\mathrm{Ph})$} & {$[\mathrm{Au}]^{+}(\mathrm{Ph}-\mathrm{CC}-\mathrm{Ph})$} & {$[\mathrm{Au}]^{+}(\mathrm{Ph}-\mathrm{CC}-\mathrm{Ph})$} & {$[\mathrm{Au}]^{+}(\mathrm{Ph}-\mathrm{CC}-\mathrm{Ph})$} & {$[\mathrm{Au}]^{+}(\mathrm{Ph}-\mathrm{CC}-\mathrm{Ph})$} \\
\hline Frag2 & & Cu-OPh & Cu-OPh & $\mathrm{Cu}-\mathrm{OPh}$ & $\mathrm{Cu}-\mathrm{OPh}$ & $\mathrm{Au}-\mathrm{OPh}$ \\
\hline \multirow[t]{5}{*}{ TS } & $\Delta \mathrm{E}_{\text {def }}$ (Frag1) & 12.79 & 13.26 & 14.59 & 15.67 & 13.97 \\
\hline & $\Delta \mathrm{E}_{\text {def }}($ Frag2) & 3.03 & 1.72 & 1.56 & 3.04 & 6.68 \\
\hline & $\Delta \mathrm{E}_{\mathrm{def}}$ & 15.82 & 14.97 & 16.15 & 18.71 & 20.65 \\
\hline & $\Delta \mathrm{E}_{\mathrm{int}}$ & -5.85 & -3.92 & -6.60 & -5.80 & -9.78 \\
\hline & $\mathrm{BE}$ & 9.97 & 11.05 & 9.55 & 12.91 & 10.93 \\
\hline \multirow{4}{*}{ Int } & $\Delta \mathrm{E}_{\text {def }}$ (Frag2) & 8.74 & 9.70 & 8.68 & 9.98 & 17.15 \\
\hline & $\Delta \mathrm{E}_{\mathrm{def}}$ & 58.14 & 58.46 & 57.92 & 61.50 & 64.48 \\
\hline & $\Delta \mathrm{E}_{\mathrm{int}}$ & -61.92 & -62.61 & -60.97 & -63.68 & -66.78 \\
\hline & $\mathrm{BE}$ & -3.78 & -4.15 & -3.05 & -2.18 & -2.30 \\
\hline
\end{tabular}

Table 8 shows further probe that corroborates the preference for the mechanism of phenoxylation in bimetallic systems to proceed more favorably when low sterically demanding ligands, like IMe, IMes or SIMes, are coordinated to the metal instead of larger ones like IPr. However, differences are scarcer than expected. In particular, IMes and SIMes ligands are thermodynamically more stable than IMe by $0.73 \mathrm{kcal} \mathrm{mol}^{-1}$ and $1.10 \mathrm{kcal} \mathrm{mol}^{-1}$, respectively, which, at the same time would be more stable than the larger IPr and IPr* ligands, ${ }^{[5,56,57]}$ but by less than $1 \mathrm{kcal} \mathrm{mol}^{-1}$. Kinetically, the energy barriers range from 9.55 kcal mol-1 for IMe to $12.91 \mathrm{kcal} \mathrm{mol}^{-1}$, not for IPr*, but for IPr. Exaggerating the sterical contribution, the $\mathrm{IPr}^{*}$ ligand gives an energy barrier even lower by $1.98 \mathrm{kcal} \mathrm{mol}^{-1}$ than for IPr, opposite to the past results with $\mathrm{QM} / \mathrm{MM}$ that hypothesized an approximated unfavorable energy barrier $\left(6.30 \mathrm{kcal} \mathrm{mol}^{-1}\right) .{ }^{[35]}$ To deepen into details of such an unexpected behavior, for the latter hindered system the deformation contribution is $6.68 \mathrm{kcal} \mathrm{mol}^{-1}$ for the phenoxide moiety, thus more than twice larger yet for the TS than for any of the other systems that range from 1.56 to $3.04 \mathrm{kcal}$ $\mathrm{mol}^{-1}$. The same occurs for the next intermediate and it is due to the distortion of the aryl groups on its $\mathrm{NHC}$ ligand to fit with the rest of the molecule. On the other hand, the NHC of the former alkyne fragments remains nearly unchanged with deformation energies that vary in a close range of $4.19 \mathrm{kcal} \mathrm{mol}^{-1}$, with $\mathrm{IPr}^{\star}$ showing the lowest distortion for the intermediate (due to the low capacity to rotate the aryl rings on the imidazole ring, and thus to deform its structure). Moreover, kinetically, IPr* enjoys the best interaction energy, $3.98 \mathrm{kcal} \mathrm{mol}^{-1}$ higher than IPr. For the sake of consistency, EDA analyses were undertaken in Table 9 as well, and the trend found out was that the more sterically hindered the
$\mathrm{NHC}$ ligand is, the larger the interaction energy, again specially high for $\operatorname{IPr}^{*}\left(11.51 \mathrm{kcal} \mathrm{mol}^{-1}\right.$ better than for IPr, and $17.70 \mathrm{kcal}$ $\mathrm{mol}^{-1}$ for IMe, to be used as a reference). The component of the interaction energy that monitors this behavior is neither of the three common ones, but the dispersion correction since it is 15.92 and $23.37 \mathrm{kcal} \mathrm{mol}^{-1}$ larger for $\mathrm{IPr}^{*}$ and IMe, respectively. The reason is due to the non-covalent interactions between the phenyl rings, i.e. $\pi-\pi$ stacking, instead of the repulsive methyl groups of the IPr, compared to the non-existing interactions when dealing with the IMe ligand. $\mathrm{NCl}$ plots computed by the NCIPLOT package ${ }^{[58,59]}$ confirmed the significant additional non-covalent interactions due to the aromatic rings of the $\mathrm{IPr}^{*}$ ligand, whereas only the ones between the phenoxide and one of the aryl rings on the diphenylacetylene for the IMe based system (see Figure 3). The plot for the IPr ligand is placed in between, and it confirms the effect of the substitution of phenyl by methyl groups, with much less favorable $\pi-\pi$ staking. ${ }^{[60,61,62,63,64]}$ Thus, $\mathrm{NCl}$ plots and EDA analyses here unveil why the sterically more hindered IPr* ligand ends up showing less unfavorable kinetics and thermodynamics than expected for the $\mathrm{C}-\mathrm{O}$ bond formation. 


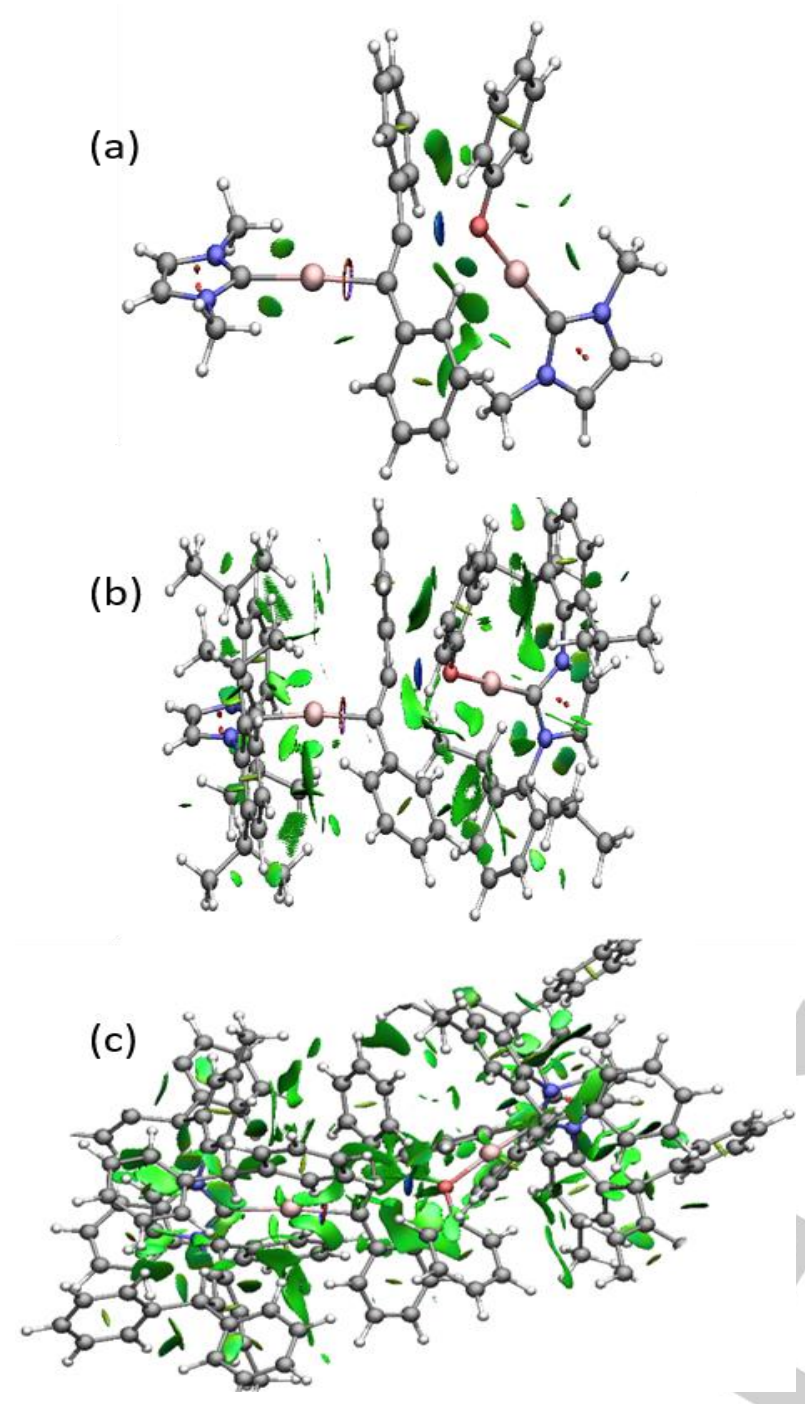

Figure 3. $\mathrm{NCl}$ plots for the transition state (TS) for the phenoxylation by $\mathrm{Cu}(\mathrm{NHC}) \mathrm{OPh}$ of $[\mathrm{Au}(\mathrm{NHC})(\mathrm{Ph}-\mathrm{CC}-\mathrm{Ph})]^{+}$(where $\mathrm{NHC}=(\mathrm{a}) \mathrm{IMe}$, (b) IPr, and (c) IPr*; being the latter slightly cut for the sake of clarity). Wave function evaluated at the M06L/Def2SVP level of theory.

Table 9. Copper and gold heterodual catalysed $\mathrm{C}-\mathrm{O}$ bond formation (relative energies with respect to both separated fragments calculated with ADF in $\mathrm{kcal} \mathrm{mol}^{-1}$ ).

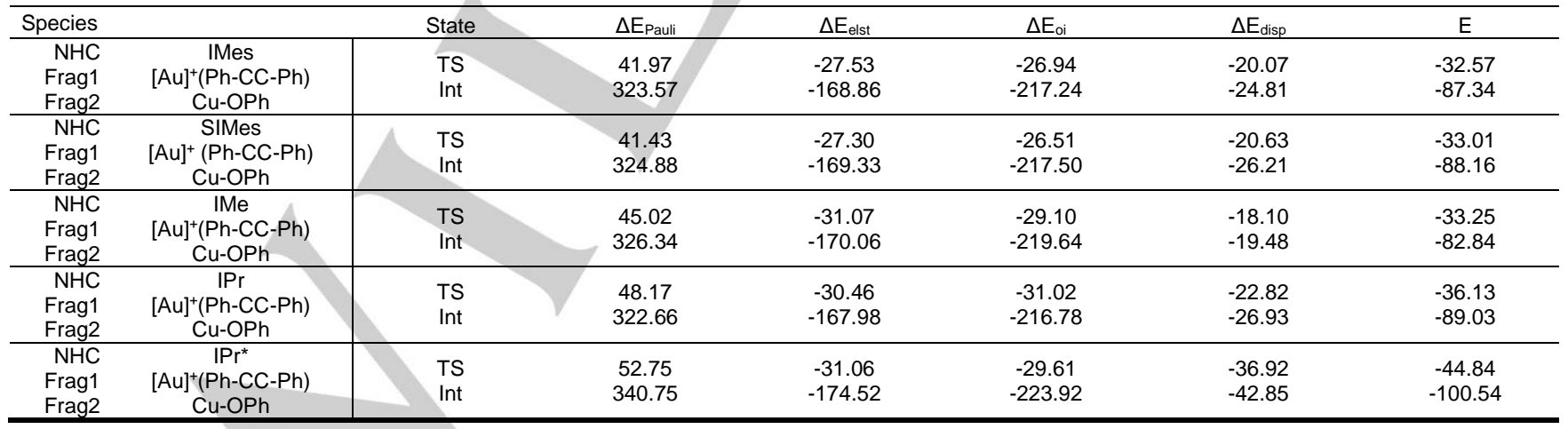

\section{Conclusions}

In summary, gold possesses an extraordinarily rich chemistry that is starting to be unraveled. Due to the strong $\pi$ interaction, gold greatly activates alkyne molecules. The corresponding intermediates are prone to the intermolecular addition of alcohols, carrying out the catalysis in the hydroalkoxylation reaction thereof. This process can be assisted by one or two metal centers. However, the dual catalysis has shown the best results, as reported by Nolan and coworkers, ${ }^{[8,65,66]}$ achieving a mild 
synthesis of trans VEs through bifunctional gold systems capable to influence both substrates, catalysing the formation of the $\mathrm{C}-\mathrm{O}$ bond between them. Nonetheless, the mechanistic explanation was still an evading shadow until next experimental, but also computational, advances in the hydrophenoxylation reaction mechanism appeared. ${ }^{[22,23,35]}$ Here the characteristic cooperativity of gold-NHC complexes has been thoroughly studied not only in homobimetallic systems, but also in heterobimetallic systems along with group 11 metals. [Cu(IPr)]-OPh compound showed a lower energy barrier than $[\mathrm{Au}(\mathrm{IPr})]-\mathrm{OPh}$ species, as the latter exhibits less nucleophilic character. Thus, this was seen to be a good synthetic strategy that grants access to VE molecules. Here we focused on the $\mathrm{C}-\mathrm{O}$ bond formation. The computational studies of the energy decomposition analysis performed in this work revealed the contributions that affect the interaction between the two separated fragments. We showed the dependence on the alcohol acidity that performs the nucleophilic attack and when its acidity increases from methanol to phenol the affinity of the interaction drops. Unlike in the alcohol, the alkyne moiety becomes more attractive towards the phenoxylation when it is supported by more electronegative substituents, i.e. phenyl groups, and even more with fluorides since then the reaction is kinetically very favoured. Additionally, we searched for the effect of less sterically demanding NHC ligands, such as IMe, IMes and SIMes, and confirmed that the reaction could proceed in a more facile way with low sterically hindered NHC ligands, but unexpectedly $\mathrm{IPr}^{*}$ showed good promising results, kinetically and thermodynamically, mostly due to the $\pi$ - $\pi$ stacking among aryl rings.

We also concluded that bimetallic systems add to the bond more electrostatic attraction energy and also that gold-phenoxide [Au(IPr)]-OPh is indeed a bad nucleophile in comparison with copper/silver-phenoxide [ $\mathrm{Cu} / \mathrm{Ag}(\mathrm{IPr})]-\mathrm{OPh}$ compound. On the other hand, when the alkyne compound is attached to gold-NHC catalyst, this acquires a higher electrophilic character than the alkynic fragment in the copper/silver-alkyne fragment.

\section{Computational Details}

All the geometry optimizations are carried out by means of DFT calculations, performed at the GGA level with the Gaussian 09 set of programs, ${ }^{[67]}$ using the BP86 functional of Becke and Perdew. ${ }^{[68,69,70]}$ The electronic configurations of the molecular systems were described with the standard split-valence basis set by using the polarisation function of Ahlrichs and coworkers for hydrogen, carbon, nitrogen, oxygen, and fluor (SVP keyword in Gaussian 09). ${ }^{[71]}$ For all metals we used the quasi-relativistic Stuttgart/Dresden effective core potential with the associated valence basis set (standard SDD keywords in Gaussian 09). ${ }^{[72,73,74]}$ The geometry optimisations were carried out without symmetry constraints, and the stationary points were characterised by analytical frequency calculations. Single-point calculations of the BP86-optimised geometries were performed by using the M06 functional[ ${ }^{[7]}$ with the triple- $\zeta$ basis set of Weigend and Ahlrichs for main-group atoms (TZVP keyword in Gaussian), ${ }^{[76]}$ whereas for all metals the SDD basis set was employed. The polarizable conductor calculation model (CPCM) was also used in these single-point calculations to model the solvent effects, using toluene as the solvent. ${ }^{[77,78,79]}$ The reported free energies in this work include energies obtained at the M06/TZVP sdd//BP86/SVP sdd level of theory corrected with zero-point energies, thermal corrections and entropy effects evaluated at $298 \mathrm{~K}$ with the BP86/SVP sdd method in the gas phase.

The general pathway to compute the binding energy $(\mathrm{BE})$ of a bimolecular system is by combining the whole deformation energy $\left(\Delta \mathrm{E}_{\mathrm{def}}\right)$, required to deform the fragments considered from their equilibrium structure to adopt the final geometry they have in the overall molecule, and the interaction energy $\left(\Delta \mathrm{E}_{\text {int }}\right)$, which is the stabilization energy when these geometrically deformed fragments interact to form the final molecule (Eq. 1).

$$
\mathrm{BE}=\Delta \mathrm{E}_{\mathrm{def}}+\Delta \mathrm{E}_{\text {int }}
$$

Following Eq. 1, $\Delta \mathrm{E}_{\text {def }}$ with Gaussian involves the deformation energies from the two fragments; $\mathrm{NHC}-\mathrm{M}(\mathrm{I})$-alkyne $\left(\mathrm{E}_{\text {def(akyne) }}\right)$ and, in dual catalysis, $\mathrm{NHC}-\mathrm{M}(\mathrm{I})$-alcohol (where $\mathrm{M}=$ metal) or simple alcohol in monometal ( $\left.E_{\text {def(alcohol })}\right)$. These englobe the difference in energy of frozen fragments extracted from an optimized structure from free fragments that are at the equilibrium structure ( $E_{F R z}$ and $E_{\text {FREE }}$ respectively) computed with the Gibbs energies in solvent $\left(G_{\text {solv }}\right)$ obtained through the molecular energies and Gibbs energies in gas and solvent. Subtracting the frozen fragments energy contribution $\left(E_{F R z}\right)$ to the total given energy of the overall molecule $\left(E_{\text {molecule }}\right)$ lead in turn to the $\Delta E_{\text {int }}$ and $B E$ as well (Scheme 1).

Additionally, Mayer Bond Orders (MBO) along with Natural Population Analysis (NPA) are included in all calculations, and that is to say, on bimolecular simulations, free 'pure' fragments (alcohol and alkyne) and frozen fragments of a given bimolecular structure.

In the $\mathrm{NCl}$ representations, we plotted the isocontour obtained for a value of 0.4 on the reduced density gradient. For the color scale, we used the interval from -0.5 to 0.5 of the second density Hessian eigenvalue, going from blue (attractive) to red (repulsive).

For the sake of consistency, single point energy calculations on the Gaussian09 optimized structures have been undertaken for the ADF calculations. Part of the geometry optimizations is extracted from past work of Poater and coworkers. ${ }^{[22,23]}$

Performing Morokuma's Energy Decomposition Analysis (EDA) using ADF package permits the division of the electronic contributions, ${ }^{[80,81]}$ in the bond between the two fragments, in a way that the stabilizing and destabilizing parts can be analysed separately for obtaining the Binding energy. The affinity of the oxygen for the triply bonded carbon is analysed in the framework of the Kohn-Sham (KS) molecular orbital model. Here, further insight on the bond nature is obtained by performing EDA analysis on these species, which via Eq. 2 permits the decomposition of the bond energy into Pauli repulsion $\left(\Delta \mathrm{E}_{\text {Pauli }}\right)$, electrostatic interaction $\left(\Delta \mathrm{E}_{\text {elst }}\right)$, and orbital interaction $\left(\Delta \mathrm{E}_{\mathrm{oi}}\right)$ terms a quantitative decomposition of the bond into electrostatic interaction, Pauli repulsion (or exchange repulsion or overlap repulsion), attractive orbital interactions $\left(\Delta \mathrm{E}_{\mathrm{oi}}\right)$, and dispersion energy is used: 


$$
\Delta \mathrm{E}_{\text {int }}=\Delta \mathrm{E}_{\text {elst }}+\Delta \mathrm{E}_{\text {pauli }}+\Delta \mathrm{E}_{\mathrm{oi}}+\Delta \mathrm{E}_{\text {disp }}
$$

The energy decomposition analyses with EDA is carried out using BP86 functional in a similar way to those for Gaussian doing gas phase single-point simulations on the optimized structures. Additionally, dispersion correction approximation is implemented by the semiclassical correction (DFT-D) which consists of the addition of a dispersion energy term to the KS energy. The latest version until the date is the one developed by Grimme in 2011 called (DFT-D3-BJ), $\left.{ }^{[82}\right]$ this dispersion correction contains accurate dispersion coefficients and cut-off radii for a wide range of elements. The basis set used is ScalarZORA/TZ2P with frozen core, with which we implement the relativistic effects of heavy metals in a proper manner. Likewise, the integration grid used here is the default one developed by Becke with a very good quality to calculate the numerical integrations.

It is important to note that ADF energy data here do not take entropy into account, resulting in different energy gauges with respect to those obtained using Gaussian. Therefore, the values obtained by each method cannot be directly compared. Actually, for the EDA analysis we use the electronic energies. However, by defining the tendencies we can match behaviors and localize major differences and qualitatively describe the mechanism for the $\mathrm{C}-\mathrm{O}$ bond formation. ADF software has proven wide performance on EDA calculations. For instance, in 2004, Nemcsok and Meyer and coworkers studied the significance and nature in the interaction between NHC ligands with group 11 metals. ${ }^{[83,84]}$ More recently, there is a report giving insights for the hydroamination reaction, analysing the $\mathrm{C}-\mathrm{N}$ bond formation process between an alkyne and an amine catalysed by rhodium and gold. ${ }^{[85]}$ Apart from these investigations, there is little information of gold systems obtained using this useful methodology.

\section{Acknowledgements}

A. P. is a Serra Húnter Fellow and ICREA Academia 2019. A. P. and J. P. are grateful to the Ministerio de Economía y Competitividad (MINECO) of Spain (projects PGC2018-097722B-I00 and CTQ2016-77558-R, MDM-2017-0767), the Generalitat de Catalunya (projects 2017SGR39 and 2017SGR348). M.G. thanks the Generalitat de Catalunya and Fons Social Europeu for the predoctoral fellowship (2018 FI_B 01120). We thank Prof. Dr. Miquel Solà for helpful comments.

Keywords: hydrophenoxylation - DFT • energy decomposition analysis $\cdot$ gold $\cdot$ alkoxylation $\cdot \mathrm{C}-\mathrm{O}$ coupling 


\section{Entry for the Table of Contents}

\section{FULL PAPER}

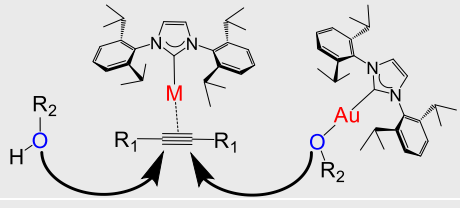

The complexity of the C-O bond formation mixing alkynes with alcohols catalysed by one or two metal moieties is unveiled by energy decomposition analyses
Miguel Ramos, Jordi Poater, Nery Villegas-Escobar, Martí Gimferrer, Alejandro Toro-Labbé, Luigi Cavallo and Albert Poater

Page No. - Page No.

Phenoxylation of Alkynes Through Mono- and Dual-Activation using Group 11 (Cu, Ag, Au) Catalysts

\section{References}

[1] C. Bruneau, P. Dixneuf, Acc. Chem. Res. 1999, 32, 311-323.

[2] G. Evano, A.-C. Gaumont, C. Alayrac, I. E. Wrona, J. R. Giguere, O. Delacroix, A. Bayle, K. Jouvin, C. Theunissen, J. Gatignol, A. C. Silvanus, Tetrahedron 2014, 70, 1529-1616.

[3] M. Chabanas, S. Brode, J. H. Teles, Angew. Chem. Int. Ed. 1998, 110, 1475-1478.

[4] P. Ha-Yeong Cheong, P. Morganelli, M. R. Luzung, K. N. Houk, F. D. Toste, J. Am. Chem. Soc. 2008, 130, $4517-4526$.

[5] Y. Odabachian, X. F. Le Goff, F. Gasgosz, Chem. Eur. J. 2009, 15, 8966-8970.

[6] A. S. K. Hashmi, T. Lauterbach, P. Nösel, M. H. Vilhelmsen, M. Rudolph, F. Rominger, Chem. Eur. J. 2013, 19, 10581065.

[7] S. Ferrer, A. M. Echavarren, Organometallics 2018, 37, 781-786.

[8] A. Gómez-Suárez, S. Dupuy, A. M. Z. Slawin, S. P. Nolan, Angew. Chem. Int. Ed. 2013, 52, 938-942.

[9] A. Gómez-Suárez, Y. Oonishi, S. Meiries, S. P. Nolan, Organometallics 2013, 32, 1106-1111.

[10] R. S. Ramón, S. Gaillard, A. Poater, L. Cavallo, A. M. Z. Slawin, S. P. Nolan, Chem. Eur. J. 2011, 17, $1238-1246$.

[11] Y. Oonishi, A. Gómez-Suárez, A. R. Martin, S. P. Nolan, Angew. Chem. Int. Ed. 2013, 52, 9767-9771.

[12] I. Abdellah, A. Poater, J.-F. Lohier, A.-C. Gaumont, Catal. Sci. Technol. 2018, 8, 6486-6492.

[13] A. Gómez-Suárez, S. P. Nolan, Angew. Chem. Int. Ed. 2012, 51, 8156-8159.

[14] C. Michon, J. Gilbert, X. Trivelli, F. Nahra, C. S. J. Cazin, F. Agbossou-Niedercom, S. P. Nolan, Biomol. Chem. 2019, $17,3805-3811$.

[15] X. Zhao, M. Rudolph, A. S. K. Hashmi, Chem. Commun. 2019, 55, 12127-12135.

[16] M. Anania, L. Jašíková, J. Jašík, J. Roithová, Org. Biomol. Chem. 2017, 15, 7841-7852.

[17] M. Asgari, C. J. T. Hyland, A. S. K. Hashmi, B. F. Yates, A. Ariafard, Catal. Sci. Technol. 2019, 9, $1420-1426$.

[18] J.-F. Greisch, P. Weis, K. Brendle, M. M. Kappes, J. R. N. Haler, J. Far, E. De Pauw, C. Albers, S. Bay, T. Wurm, M. Rudolph, J. Schulmeister, A. S. K. Hashmi, Organometallics 2018, 37, 1493-1500.

[19] R. Dorel, A. M. Echavarren, Chem. Rev. 2015, 115, 9028-9072.

[20] L. Jaš́íková, M. Anania, S. Hybelbauerová, J. Roithová, J. Am. Chem. Soc. 2015, 137, 13647-13657.

[21] L. Jaš́íková, Ś. Janková, S. Hybelbauerová, J. Roithová, Angew. Chem. Int. Ed. 2012, 51, 8378-8382.

[22] A. Gómez-Suárez, Y. Oonishi, A. R. Martin, S. V. C. Vummaleti, D. J. Nelson, D. B. Cordes, A. M. Z. Slawin, L. Cavallo, S. P. Nolan, A. Poater, Chem. Eur. J. 2016, 22, 1125-1132.

[23] È. Casals-Cruañas, O. F. González-Belman, P. Besalú-Sala, D. J. Nelson, A. Poater, Org. Biomol. Chem. 2017, 15, 64166425 .

[24] A. Fürstner, P. W. Davies, Angew. Chem. Int. Ed. 2007, 46, 3410-3449.

[25] P. Nun, S. Dupuy, S. Gaillard, A. Poater, L. Cavallo, S. P. Nolan, Catal. Sci. Technol. 2011, 1, 58-61. 
[26] M. Lein, M. Rudolph, S. K. Hashmi, P. Schwerdtfeger, Organometallics 2010, 29, 2206-2210.

[27] G. Kovács, A. Lledós, G. Ujaque, Organometallics 2010, 29, 3252-3260.

[28] L. D'Amore, G. Ciancaleoni, L. Belpassi, F. Tarantelli, D. Zuccaccia, P. Belanzoni, Organometallics 2017, 36, $2364-$ 2376.

[29] D. Zuccaccia, L. Belpassi, L. Rocchigiani, F. Tarantelli, A. Macchioni, Inorg. Chem. 2010, 49, 3080-3082.

[30] L. Rocchigiani, M. Q. Jia, M. Bandini, A. Macchioni, ACS Catal. 2015, 5, 3911-3915

[31] L. Biasiolo, M. Trinchillo, P. Belanzoni, L. Belpassi, V. Busico, G. Ciancaleoni, A. D’Amora, A. Macchioni, F. Tarantelli, D. Zuccaccia, Chem. Eur. J. 2014, 20, 14594-14598.

[32] G. Ciancaleoni, L. Biasiolo, G. Bistoni, A. Macchioni, F. Tarantelli, D. Zuccaccia, L. Belpassi, Organometallics 2013, $32,4444-4447$.

[33] G. Ciancaleoni, L. Belpassi, D. Zuccaccia, F. Tarantelli, P. Belanzoni, ACS Catal. 2015, 5, 803-814.

[34] L. Biasiolo, A. Del Zotto, D. Zuccaccia, Organometallics 2015, 34, 1759-1765.

[35] F. Nahra, F. Lazreg, S. Guidone, A. Gómez-Herrera, C. S. J. Cazin, Dalton Trans. 2017, 46, 2439-2444.

[36] N. Wheatley, P. Kalck, Chem. Rev. 1999, 12, 3379-3420.

[37] J. J. Hirner, Y. Shi, S. A. Blum, Acc. Chem. Res. 2011, 44, 603-613.

[38] G. R. Gupta, J. Shah, K. S. Vadagaonkar, A. G. Lavekar, A. R. Kapdi, Org. Biomol. Chem. 2019, 17, 7596-7631.

[39] O. F. González-Belman, J. O. C. Jiménez-Halla, F. Nahra, C. S. J. Cazin, A. Poater, Catal. Sci. Technol. 2018, 8, 36383648.

[40] V. D’Elia, A. A. Ghani, A. Monassier, J. Sofack-Kreutzer, J. D. A. Pelletier, M. Drees, S. V. C. Vummaleti, A. Poater, L. Cavallo, M. Cokoja, J.-M. Basset, F. E. Kühn, Chem. Eur. J. 2014, 20, 11870-11882.

[41] V. D’Elia, H. Dong, A. Rossini, C. Widdifield, S. V. C. Vummaleti, Y. Minenkov, A. Poater, E. Abou-Hamad, J. Pelletier, L. Cavallo, L. Emsley, J. M. Basset, J. Am. Chem. Soc. 2015, 137, 7728-7739.

[42] S. V. C. Vummaleti, S. P. Nolan, L. Cavallo, G. Talarico, A. Poater, Eur. J. Inorg. Chem. 2015, 4653-4657.

[43] O. Sodpiban, S. Del Gobbo, S. Barman, V. Aomchad, P. Kdkhunthod, S. Ould-Chikh, A. Poater, V. D'Elia, J.-M. Basset, Catal. Sci. Technol. 2020, DOI: $10.1039 / \mathrm{c} 9$ cy01642b

[44] A. Poater, L. Falivene, C. A. Urbina-Blanco, S. Manzini, S. P. Nolan, L. Cavallo, Dalton Trans. 2013, 42, 7433-7439.

[45] S. V. C. Vummaleti, D. J. Nelson, A. Poater, A. Gómez-Suarez, D. B. Cordes, A. M. Z. Slawin, S. P. Nolan, L. Cavallo, Chem. Sci. 2015, 6, 1895-1904.

[46] P. Nun, S. Gaillard, A. Poater, L. Cavallo, S. P. Nolan, Org. Biomol. Chem. 2011, 9, 101-104.

[ 47 ] Engineering ToolBox (2017). Phenols, alcohols and carboxylic acids - pKa values. [online] Available at: https://www.engineeringtoolbox.com/paraffinic-benzoic-hydroxy-dioic-acids-structure-pka-carboxylic-dissociation-

constant-alcohol-phenol-d_1948.html [Accessed July 12th, 2019].

[48] R. P. Bell, Proc. R. Soc. London, Ser. A 1936, 154, 414-429.

[49] M. G. Evans, M. Polanyi, J. Chem. Soc., Faraday Trans. 1936, 32, 1333-1360.

[50] I. Mayer, Chem. Phys. Lett. 1983, 97, 270-274.

[51] I. Mayer, Int. J. Quantum Chem. 1984, 26, 151-154.

[52] L. Falivene, Z. Cao, A. Petta, L. Serra, A. Poater, R. Oliva, V. Scarano, L. Cavallo, Nat. Chem. 2019, 11, 872-879.

[53] A. Poater, B. Cosenza, A. Correa, S. Giudice, F. Ragone, V. Scarano, L. Cavallo, Eur. J. Inorg. Chem. 2009, 1759-1766.

[54] L. Falivene, R. Credendino, A. Poater, A. Petta, L. Serra, R. Oliva, V. Scarano, L. Cavallo, Organometallics 2016, 35, 2286-2293.

[55] G. Li, T. Zhou, A. Poater, L. Cavallo, S. P. Nolan, M. Szostak, Catal. Sci. Technol. 2020, DOI:10.1039/C9CY02080B.

[56] G. Li, P. Lei, M. Szostak, E. Casals-Cruañas, A. Poater, L. Cavallo, S. P. Nolan, ChemCatChem 2018, 10, 3096-3106.

[57] L. M. Azofra, R. M. P. Veenboer, L. Falivene, S. V. C. Vummaleti, A. Poater, S. P. Nolan, L. Cavallo, Phys. Chem. Chem. Phys. 2019, 21, 15615-15622.

[58] E. R. Johnson, S. Keinan, P. Mori-Sanchez, J. Contreras-Garcia, A. J. Cohen, W. Yang, J. Am. Chem. Soc. 2010, 132, 6498-6506.

[59] J. Contreras-Garcia, E. Johnson, S. Keinan, R. Chaudret, J. P. Piquemal, D. Beratan, W. Yang, J. Chem. Theory Comput. 2011, 7, 625-632.

[60] J. Masdemont, J. A. Luque-Urrutia, M. Gimferrer, D. Milstein, A. Poater, ACS Catal. 2019, 9, 1662-1669.

[61] J. Poater, M. Gimferrer, A. Poater, Inorg. Chem. 2018, 57, 6981-6990.

[62] J. A. Luque-Urrutia, A. Poater; M. Solà, Chem. Eur. J. 2020, DOI: 10.1002/chem.201904650.

[63] S. Dehghani, S. Sadjadi, N. Bahri-Laleh, M. Nekoomanesh-Haghighi, A. Poater, Appl. Organomet. Chem. 2019, 33, e4891.

[64] C. J. Richmond, S. Escayola, A. Poater, Eur. J. Inorg. Chem. 2019, 2101-2108.

[65] A. Cavarzan, A. Scarso, P. Sgarbossa, G. Strukul, J. N. H. Reek, J. Am. Chem. Soc. 2011, 133, 2848-2851.

[66] A. C. H. Jans, A. Gómez-Suárez, S. P. Nolan, J. N. H. Reek, Chem. Eur. J. 2016, 22, 14836-14839.

[67] Gaussian 09, Revision C.01, M. J. Frisch, G. W. Trucks, H. B. Schlegel, G. E. Scuseria, M. A. Robb, J. R. Cheeseman, G. Scalmani, V. Barone, B. Mennucci, G. A. Petersson, H. Nakatsuji, M. Caricato, X. Li, H. P. Hratchian, A. F. Izmaylov, J. Bloino, G. Zheng, J. L. Sonnenberg, M. Hada, M. Ehara, K. Toyota, R. Fukuda, J. Hasegawa, M. Ishida, T. Nakaj ima, Y. 
Honda, O. Kitao, H. Nakai, T. Vreven, J. A. Montgomery, Jr. , J. E. Peralta, F. Ogliaro, M. Bearpark, J. J. Heyd, E. Brothers, K. N. Kudin, V. N. Staroverov, R. Kobayashi, J. Normand, K. Raghavachari, A. Rendell, J. C. Burant, S. S. Iyengar, J. Tomasi, M. Cossi, N. Rega, J. M. Millam, M. Klene, J. E. Knox, J. B. Cross, V. Bakken, C. Adamo, J. Jaramillo, R. Gomperts, R. E. Stratmann, O. Yazyev, A. J. Austin, R. Cammi, C. Pomelli, J. W. Ochterski, R. L. Martin, K. Morokuma, V. G. Zakrzewski, G. A. Voth, P. Salvador, J. J. Dannenberg, S. Dapprich, A. D. Daniels, Ö. Farkas, J. B. Foresman, J. V. Ortiz, J. Cioslowski, and D. J. Fox, Gaussian, Inc., Wallingford CT, 2009.

[68] A. Becke, Phys. Rev. A 1988, 38, 3098-3100.

[69] J. P. Perdew, Phys. Rev. B 1986, 33, 8822-8824.

[70] J. P. Perdew, Phys. Rev. B 1986, 34, 7406-7406.

[71] A. Schäfer, H. Horn, R. Ahlrichs, J. Chem. Phys. 1992, 97, 2571-2577.

[72] U. Häussermann, M. Dolg, H. Stoll, H. Preuss, Mol. Phys. 1993, 78, 1211-1224.

[73] W. Kuechle, M. Dolg, H. Stoll, H. Preuss, J. Chem. Phys. 1994, 100, 7535-7542.

[74] T. Leininger, A. Nicklass, H. Stoll, M. Dolg, P. Schwerdtfeger, J. Chem. Phys. 1996, 105, 1052-1059.

[75] Y. Zhao, D. G. Truhlar, Theor. Chem. Acc. 2008, 120, 215-241.

[76] F. Weigend, R. Ahlrichs, Phys. Chem. Chem. Phys. 2005, 7, 3297-3305.

[77] V. Barone, M. Cossi, J. Phys. Chem. A 1998, 102, 1995-2001.

[78] J. Tomasi, M. Persico, Chem. Rev. 1994, 94, 2027-2094.

[79] M. Cossi, N. Rega, G. Scalmani, V. Barone, J. Comp. Chem. 2003, 24, 669-681.

[80] K. Morokuma, J. Chem. Phys. 1971, 55, 1236.

[81] K. Morokuma, Acc. Chem. Res. 1977, 10, 294-300.

[82] L. Goerigk, S. Ehrlich, S. Grimme, J. Comp. Chem. 2011, 32, 1456-1465

[83] D. Nemcsok, K. Wichmann, G. Frenking, Organometallics 2004, 23, 3640-3646.

[84] X. Hu, I. Castro-Rodríguez, K. Olsen, K. Meyer, Organometallics 2004, 23, 755-764.

[85] A. C. Ríos, PhD Dissertation: Mechanistic Insights Into Metal-Catalyzed Hydroamination Reactions, 2017. 